\title{
Örgütsel Süreçlerde İşlev Bozukluğunun İşlevsiz Momentum ve Abilene Paradoksu Ekseninde Tahlili
}

\author{
Ahmet Hakan YÜKSEL*
}

\begin{abstract}
$\ddot{O} Z$
Örgütsel işlevsizlik, örgütlerdeki iş süreçlerinde belirgin hale gelen ve sürdürüldüğ̈̈nde maliyeti ă̆ır sonuçların doğacağına işaret eden semptom ve sinyallerin göz ardı edilmesi durumunu tarif etmektedir. Örgüt üyelerinin söz konusu semptom ve sinyalleri kasitl olarak göz ardı etmelerinin yönetsel, bilişsel ve psikolojik boyutları bulunmaktadır. Bu makalede, bireylerin hataları fark edip süreçleri yeniden ayarlamak yerine işlevsizliğin devinimine uyum sağlamayı tercih etmelerinin altyapısını inceleyen işlevsiz momentum yaklaşımı, örgütlerin neden yönelmeyi arzu ettikleri istikametin tam tersine yol alma eğiliminde olduğunu inceleyen Abilene paradoksu ekseninde tahlil edilecektir. Örgütsel işlevsizliğin bir ögrenmeme hali olduğu yorumundan hareketle makaledeki tahlil tek-döngülü ve çift-döngülü ögrenme modelleri ile iliş̧ilendirilecektir.
\end{abstract}

Anahtar kelimeler: Örgütsel işlevsizlik, örgütlerde davranışsal patoloji, çatışma.

JEL Sinıflandırması: L29, M12

\section{Analysis of organizational dysfunction: Dysfunctional momentum and the Abilene Paradox}

\begin{abstract}
Organizational dysfunction refers to ignoring the salient symptoms and cues about emerging inefficiencies in work processes. Dysfunctional momentum occurs when people fail to pause and recalibrate inefficient work processes. Abilene paradox deals with why organizations frequently take actions in contradiction to their original intentions. This article intends to comprehend the psychodynamics of turning a blind eye to the dysfunctional organizational processes through incorporation of the insight provided by dysfunctional momentum and Abilene paradox into the analysis.
\end{abstract}

Keywords: Organizational dysfunction, behavioral pathology in organizations, conflict.

JEL Classification: L29, M12

\section{GíRIŞ}

Bauman (2000/2012) yüzyılın başında yayınlandığından beri hayli ses getiren 'Liquid Times' adlı eserinde çağımıza damga vuran dönüşümü, katı halden sıvı (akışkan) hale geçiş olarak betimlemektedir. Katı halde olan maddelerin uzaysal düzlemde tanımlanabilir belirgin biçimleri vardır. Atomik yapıları gereği bütünlüklerini koruyacak şekilde zamanın değiştirici etkilerine direnerek, bir yerde zamanın anlamını yitirmesine neden olurlar. Buna karşın sıvılar, bulundukları ortamda anlık biçimler alabilseler dahi, bunu uzun süre muhafaza etme eğiliminde

\footnotetext{
* Yardımcı Doçent, Işık Üniversitesi İktisadi ve İdari Bilimler Fakültesi İşletme Bölümü, Üniversite Sokak, No.2, 34980, Şile-İstanbul.
} 
değillerdir. Zamana direnmek bir yana, zaman ile birlikte devinme, daha doğrusu, zaman ile 'akma' özellikleri vardır.

Görünen o ki, karşımıza çıkan sosyal ve örgütsel yeni oluşumları doğrusal (linear) düşünce alışkanlıkları ile idrak edebilme imkanı artık bulunmamaktadır. Bütünün etkileşime giren parçaları nitel olarak özgün durumların belirmesine neden olmaktadır. Eşi görülmemiş miktarda veri ve enformasyon kompleks bir küresel sistemde gerçek zamanlı olarak akmaktadır. Internet ortamında, tüm internet ağında son yirmi yılda üretilenden daha fazla veri, saniye bazında mevcut havuza eklenmektedir (McAfee ve Brynjolffson, 2012: 62). Büyük veri (big data) kavramı, özellikle son birkaç yılda yönetsel yaklaşımların şekillenmesinde yadsınamaz bir etki sahibi olmuştur. Kamu veya özel tüm örgütler üstel artış gösteren veri hacmi ile başa çıkabilmenin yollarını bulmak ve sunduğu firsatlardan yararlanabilmek için yöntemler geliştirme çabasına girmişlerdir (Altunışı, 2015: 46). Büyük veri, teknolojik altyapıların yeniden tasarlanmasının ötesinde örgütlerin kültürel kodlarında yeni yönelimleri zaruri kılmıştır (Davenport, 2014: 18). Logaritmik artış gösteren veri hacminin yoruma muhtaç olması, örgütsel fenomeni sabit bağlama (context) dayalı neden-sonuç ilişkileri ile açıklamaya çalışan Newton paradigmasının terkedilmesi ile sonuçlanacak şekilde yerini, anlamlandırma, yorumlama ve 'neden' ile 'sonuç' arasındaki ilişkinin refleksif (reflexive) olarak birbirini sürekli şekillendirdiği kabulü üzerine kurulu, doğrusalı terk eden (nonlinear) kuramsal arayışlara bırakmıştır. (Tsoukas ve Cummings, 1997: 656)

Bir yandan yukarıda bahsi geçen bir olgu zuhur ederken (emergence) öte yandan, yakın dönem vakalar incelendiğinde, veri ve enformasyonu yorumlamaktaki kifayetsizlikler nedeniyle sonuçlarının maliyeti oldukça ağır olan örgütsel çöküşlerin küresel gündemi meşgul ettiği görülmektedir. 9/11 olarak anılan ve küresel siyasi akışı geri dönülmez biçimde etkileyen Amerika Birleşik Devletleri'ne (ABD) yönelik 2001 yılındaki saldırıdan önce ulusal güvenlikten sorumlu örgütlerin sinyalleri okumadaki ihmali (Catino, 2013: 13); denetçilere (auditor) ve denetim (auditing) mekanizmalarına itimadın sarsılarak küresel finansal sistemin sağlıklı işleyişinde hayati öneme sahip güven kavramının zedelenmesine neden olan Enron vakası (Bazerman ve Watkins, 2004: 63); 1986 yılında uzay mekiği Challenger'ın infilakına neden olan teknik sorunlara dair önceden beliren semptomların Ulusal Havacılik ve Uzay Dairesi (NASA) çalışanları tarafindan göz ardı edilmesi (Finkelstein, 2004: 197); Volkswagen firmasının ABD'ye sattığı dizel araçların egzoz emisyon seviyeleri üzerinde yaptığ yanıltıcı müdahale (Hotten, 2015) ve tüm tutarlı bilimsel kanıtlara rağmen küresel 1sınma sorununu çözmedeki atalet (Bazerman ve Watkins, 2004: 90) gibi örnekler sayılabilir.

$\mathrm{Bu}$ gibi örnekler örgütlerde 'işlevsizlik' olarak anılan durumun yansımalarıdır. İşlevsizlik kavramı ile gelecekte örgütün ana faaliyet alanına doğrudan etki edecek potansiyel tehditlerin iş süreçlerinde teşhis edilmesine karşın bulguların adeta yok sayılarak yola devam edilmesi kastedilmektedir. İşlevsizlik konusuna özellikle son on yılda artan bir vurgu olmakla birlikte örgütsel bağlamda 
bireylerin entropinin ${ }^{1}$ üstesinden gelme hususundaki beceri eksikliği (Salancik, 1977a) uzunca bir süre önce ifade edilmiştir.

Burada akla gelen temel soru şudur: Veri ve enformasyonun bu denli erişilebilir ve işlenebilir olduğu bir zaman diliminde nasıl oluyor da yaklaşan felaketi işaret eden tüm sinyallere ve uyarı niteliğindeki semptomlara rağmen örgütler gereken önlemleri alamıyorlar? Şişkin bürokratik yapıları ya da örgüt üyelerinin (çalışanların ve yöneticilerin) yetkinliklerinin yetersizliği gibi nedenleri öne sürmek Finkelstein'e (2004: 194) göre ikna edici olmaktan uzaktır. Zira, gereğinden büyük, çok katmanlı bürokratik yönetsel tasarıma sahip birçok yapı son derece yüksek hacimli veri ve enformasyonu başarıyla işleyerek bunlardan çıkarsama yapmayı becerebilmektedir. Çalışanların yetkinliği açısından bakıldığında ise yukarıdaki örneklerde bahsi geçen örgütsel yapılanmaların son derece nitelikli ve yetkin çalı̧anları istihdam ettikleri görülmektedir. Örgütsel işlevsiz ve söz konusu işlevsizliğin momentumunu muhafaza etme eğilimi yönetsel, sosyolojik, bilişsel ve psikolojik boyutları olan bir konu olup makalede bu kavram işlevsiz momentum ve Abilene paradoksu ekseninde irdelenecektir. Bu iki yaklaşımın tahlil ekseni olarak seçilmelerinin iki sebebi bulunmaktadır. Bunlardan ilki, her iki yaklaşımda da başarısızlığın önceden görülebilmesine karşın ataletin (süredurum) muhafaza ediliyor olmasıdır. Diğeri ise, her iki yaklaşımda da başarısızlığa götüren rotanın değiştirilememesine gerekçe olarak psikolojik faktörlerin öne sürülmesidir.

\section{I. ÖRGÜTSEL İ̧LEVSIZLLIK}

Örgütlerde işlevsizlik ile ilgili yaklaşımlar irdelendiğinde işlevsizliğin bağl1lık (commitment) kavramı ile ilişkisi dikkat çekmektedir. Salancik (1977b: 62) bağl1lığın örgüt üyelerinin davranışları üzerindeki belirleyici etkisinden bahsetmiştir. Bağlılı̆̆ sürdürülebilirliğini sağlayan hareketler ve inançlar olarak tanımlayarak faydalı ve zararlı yönlerine değinmiş, tutumsal ve davranışsal olarak sınıflandırmıştır. Tutumsal boyutu sebepler-sonuçlar ekseninde ölçülebilen psikolojik bir hal olarak tanımlarken, davranışsal boyut, bireylerin işi isteyerek ve alenen devam ettirmelerine imkan veren irade kullanımı (kişisel sorumluluğun kabulü) ve davranışın geri dönülmezliği (geriye alamama) ilkeleri ile ortaya koymuştur (Meyer vd., 2008: 36). Bir davranış sergilendiğinde artık geri alınamaz ve davranışın ürünü olan yeni ortamın sunacağı seçenekler kısıtlıdır. Dolayısıyla bireyin vereceği kararlar ve yeni duruma tepki olarak sergileyeceği davranışlar daima orijinal davranışın yörüngesinde biçimlenecektir.

Stratejik hedefleri doğrultusunda ilerleyen bir örgütte bağl1lık, örgüt üyelerinin işleri tanımlanmış çerçevede, zamanında ve istenilen performans düzeyinde göreceklerinin bir taahhüdü olarak görülebilir. Öte yandan, gelecekte

\footnotetext{
${ }^{1}$ Sistem çıktı ürettiğinde, bir sonraki üretim döngüsünde faydayı elde edebilmek için ilave enerjiye ihtiyaç duyulması durumudur. Aynı zamanda bir sistemdeki düzensizlik halinin de ölçüsü olarak kullanılan entropi sosyal sistemler perspektifinde ele alındığında kaynakların yararlı işe dönüştürülmesi sürecinde yaşanan kayıpları ifade etmektedir (Erol, 2001: 129).
} 
doğması hayli olası bir riske işaret eden sinyallerin ve semptomların örgüt üyeleri tarafından yok sayılarak değerlendirilmeye alınmaması noktasında bağlılık marazi bir hal almaktadır. Bağlılık, körü körüne olarak nitelenebilecek bir hal aldığında örgüt gerçekleri olduğu gibi görme yetisini kaybederek adeta miyop olur. Türk Dil Kurumu tarafından 'uzakgörmez' olarak tanımlanan miyopluk, Catino (2013) tarafından örgütsel işlevsizliği tarif etmekte kullanılmış bir metafordur. Catino’ya (2013:126) göre örgütsel miyopluk, örgütün hakim inanç ve uygulamalarını sorgulamadan sürdürmekteki 1srarı ve bunun neden olacağı öngörüden yoksun kararları temsil etmektedir.

Örgütsel öğrenme perspektifinden bakıldığında işlevsizliğin aslında bir 'öğrenmeme' hali olduğunu söylemek hatalı olmayacaktır. Argyris (1994: 77) yöneticilerin astlarıyla kurduğu iletişim kurma yöntemlerinin potansiyel tehditlerin tespit edilmesinde büyük önem taşıyan enformasyonun açığa çıkmasını engellediğini ifade etmektedir. Argyris'e (1994)göre bu durum örgütsel öğrenme ile yakından alakalıdır. Son elli yılda örgüt çevresindeki belirsizlik ortamına artarak yapılan vurgu örgütsel uyum kavramının dinamik bir süreç olarak kabul edilmesine neden olmuştur (Miles vd., 1978: 547). Özellikle daha kaliteli, hızlı ve maliyetetkin üretimi mümkün kılacak özgün kabiliyetlerin (teknoloji, tasarım, yöntem) ortaya çıkmasını sağlayacak olan süreç inovasyonu için örgütsel öğrenme hayati nitelik taşımaktadır (Oke vd., 2007: 738). Bunun başarılabilmesi için de örgüt üyelerinin hataları tespit ederek onarıcı önlemlerin hayata geçebileceği ilişkiler tesis etmeleri ve çevresel değişimleri içselleştirmeleri gerekmektedir (Koçoğlu vd., 2011: 74; Schein, 2004: 395).

Argyris'in (1994: 78) öne sürdüğü tek-döngü ve çift-döngü öğrenme modelleri örgütsel işlevsizlik konusunun öğrenme eksenli incelenmesinde yol gösterici niteliktedir. Tek-döngülü öğrenme, tek boyutlu sorular sorarak tek boyutlu cevapların peşine düşerken, çift-döngülü öğrenme soruyu, sorana döndürerek gerçekliğin sorgulanmasını amaçlar. Argyris (1994) ikisi arasındaki farkı izah edebilmek amaciyla yaygın olarak bilinen termostat örneğinden istifade etmektedir. Termostat, kendini açıp kapatarak ortam ısısının önceden ayarlanmış seviyede kalmasını sağlayan bir cihazdır. Tek-döngülü öğrenme, tıpkı termostat gibi, tebliğ edilmiş hedefleri ve örgütsel süreç tasarımlarını sorgulamadan kabullenmeyi ve performansı bu ölçütlere göre ayarlamayı amaçlar. Termostat örneği çift-döngülü öğrenmeye uyarlandığında ise bu model, derecesi önceden tespit edilmiş 1s1 seviyesinin ortam şartları göz önüne alındığında optimum olup olmadığını ve mevcut 1sıtma sisteminin bunun sağlanması için uygun olup olmadığını irdeleyecek; hatta daha da ileri giderek ortam dahil tüm düzeneğin başlangıçta neden o şekilde bir araya getirildiğini sorgulayacaktır. Çift-döngülü öğrenme modelinin rekleksif nitelik taşıdığını ifade etmek yerinde olacaktır. Zira, öğrenme süreci doğrusal ve tek yönlü olmanın ötesinde esnek ve öğrenen odaklı olmalı; öğrenme sürecindeki bireyin diğer bireylerle etkileşime girerek bilgiye erişmesine olanak tanımalıdır (Dyke, 2009: 306). Refleksif öğrenme süreci deneyimden yola 
çıkarak bireyin diğerleri ile eleştirel bir iletişim kurmasını gerektirir (Dyke, 2006: 108).

İşlevsizliğin maliyetinin artmasına neden olan tek-döngülü öğrenme modeli, öğrenmeyi ve buna bağlı nitel değişimi mümkün kılacak (rahatsız edici olsa bile) süreç bilgilerini baskılamakta, örgüt üyelerinin bireysel davranışlarının sorumluluğunu almalarını engellemektedir (Argyris, 1994: 85). Tek-döngülü öğrenme modeli işlevsiz momentumun oluşmasına ve muhafazasına altyapı hazırlamaktadır.

\section{II. İŞLEVSIZZ MOMENTUM}

Barton ve Sutcliffe (2009) örgütlerin tüm sinyal ve semptomlara rağmen durmaksızın felakete sürüklenişlerini tabir etmek için bu kavramı öne sürmüş ve "örgütün gittiği doğrultunun değişmesini gerektiren işaretlerin varlığına karşın süreçleri gözden geçirmek ve yeniden ayarlamak (kalibrasyon) için ara vermeden, bireylerin ilk hedeflerine doğru çalışmaya kesintisiz devam etmeleri” (Barton ve Sutcliffe, 2010) olarak tanımlamışlardır. Momentum, enerjinin korunumu ile alakalı fizik bilim alanında kullanılan niceliksel bir kavramdır ${ }^{2}$. Momentum metaforundan istifade edilmesinin ana sebebi kesintisizlik vurgusudur. Barton ve Sutcliffe (2010: 71), işlevsiz momentumun yapısını incelerken beş ana bileşene değinmişlerdir.

Bunlardan ilki bireylerin akışı muhafaza eğilimini ifade eden devinim oryantasyonudur. Örgütlerde çalışanlar rekabetçi olan bir piyasa ortamında, fayda sağlayan işleri zamanında ve performans beklentileri ile örtüşecek şekilde yerine getirmek durumundadırlar. Bu nedenle, öngörülebilir gelecekte doğması muhtemel sorunlara dair uyarıcı niteliği taşıyan semptomlardan bahsedilmesi özellikle yöneticiler tarafından arzu edilmeyebilir. Bu semptomların değerlendirilebilmesi için durup zaman harcamak gerektiğinden iş akışını sekteye uğratacak müdahaleler göz ard1 edilir ve böylece sorun derinleşse de işlevsiz momentum korunmuş olur.

İkinci bileşen ise esnek olmayan planlamadır. Planlama örgütsel iş süreç mimarisinin tasarımında önemli rol oynayan ve örgütsel hedeflere ulaşmanın teminat altında olmasına imkan veren temel yönetsel işlevlerden birisidir (Fayol, 1949: 50, Linstead, vd., 2009: 175). Yöneticilerin bilinçli karar almaları ve bu kararları uygulama yöntemlerini belirlemeleri için planlar gerekli olmakla birlikte esnek olmaları da bir o kadar önemlidir (Patnaik, 2012: 23). Çalışanlar ve yöneticiler için planın belirlediği kulvarın dışına çıkmanın algısal maliyeti hayli yüksektir. İşleri görenlerin performansı, plan ölçüt alınarak değerlendirilmektedir. $\mathrm{Bu}$ nedenle gelecekteki tehlikeyi işaret eden sinyaller belirgin olmasına karşın bunların dile getirilmesinden kaçınılır (Barton ve Sutcliffe, 2010: 71).

Üçüncü bileşene dalga etkisi olarak anılmaktadır. Anlamlı olamayacak kadar basit olduğu düşünülen küçük sapmalar, örgütsel bütünü oluşturan tüm parçaların birbirleriyle etkileşim halinde olduğu göz önüne alındığında, son derece

\footnotetext{
${ }^{2}$ Bir cisimdeki bütün kütleleri hızları ile çarpıp bunlar toplandığında parçacıkların toplam momentum elde edilir ve toplam momentum miktarı korunur. Enerji ve momentum birbirleriyle çok yakından ilişkili oldukları ortaya konmuştur (Feynman, 1995: 100).
} 
ciddi sorunların ortaya çıkmasına neden olabilir. Örgütsel akışta istikrar görüntüsü hakim olsa da iş süreçlerindeki örtük semptomlar süreçler arası etkileşim sonrası özgün sorunların ortaya çıkması ile sonuçlanabilir. Elbette bu noktada dikkat çekilmesi gereken bir diğer husus da örgüt üyesinin veri ve enformasyonu tanıyabilecek ve yorumlayabilecek altyapıya sahip olup olmadığıdır (Finkelstein, 2004: 195). Başlangıçta anlamlandırılamayan sinyaller ve semptomlar önemsiz olarak değerlendirilir.

Dördüncüsü ise rasyonelleştirme olarak ifade edilmektedir. Sahip olduğumuz bilgi, düşünce ve inançların onaylanması insanları memnun ederken, aksi şekilde, sahip olduğumuz bilgi, düşünce ve inançların yanlış olduklarını ortaya koyan bulgularla yüzleşmek ise bir o kadar rahatsızlık vericidir. Bundan kaçınabilmek için çalışanlar ve yöneticiler öncelikle semptomları, yok sayamasalar dahi, normalleştirme eğilimine girerler. Normalleştirmeden kastedilen, yürürlükteki bilgi, düşünce veya inancın sanıldığı kadar doğru olmadığını ortaya koyan yeni verilere göre ölçütlerin yeniden ayarlanmasıdır. Bu rahatsızlıktan kaçınmanın bir diğer yolu da çalışanların ve yöneticilerin doğru bildiklerini onaylayacak kanıtlara yönelmeleri ve durumu yorumlarken bu kanıtlara ağırlık vermeleridir (Hammond vd., 1998: 6). Örgütsel iş süreçlerindeki yapısal sorunları teğet geçecek şekilde seçici veri toplamak kısa vadeli faydayı ön plana çıkararak olgulara yüzeysel neden-sonuç ilişkilerinden hareketle yaklaşılmasına neden olmakta, bilimsel yöntemleri ise amacından uzaklaştırarak kullanışlı makyaj malzemesine dönüştürmektedir (Argyris, 1994: 80). Sahip olunan bilgi, fikir ve inançları doğrulayacak verilerin temel alınması, öğrenme için olmazsa olmaz (sine qua non) kabul edilen döngüsel yorumlamanın (interpretation) önünü tıkayarak işlevsiz momentumun ivmesini artırmaktadır.

Barton ve Sutcliffe (2010: 71) işlevsiz momentuma sebep olacak son bileşen olarak ise uzmanlığa gereğinden fazla güvenmeyi ortaya koymaktadırlar. İşlevsiz momentumu artıran önemli bir unsur olan uzmanlığa aşırı güven, yöneticilerin sahip oldukları üst seviye eğitim, mesleki deneyim, güç ve mevki nedeniyle çalışanların bu kişilerin gelecekteki muhtemel bir soruna dair semptomları teşhis edebilecek ve sinyalleri doğru okuyabilecek kapasitede olduklarına inanmalarına sebep olmaktadır. Bu varsayım altında örgüt üyeleri, ya gördüklerini dile getirmemeyi tercih ederler ya da 'onlar nasıl olsa fark ederler' inancıyla rehavete kapılırlar. Uzmanlığa aşırı güven, 'onlardan iyi mi bileceğim' sözünde belirgin olduğu şekliyle, düşünmeye gerek bırakmaması nedeniyle insanları olup bitenler karşısında kayıtsız bırakabilmektedir (Cialdini, 2009: 181).

Barton ve Sutcliffe (2009: 1,330), Salancik'in (1977a, 1977b) yukarida bahsi geçen bağlılık kavramına paralel olarak, işlevsiz momentumu bir kifayetsizlik olarak değil de, örgüt üyelerinin beliren sinyal ve semptomları anlamlandıramama hali olarak tarif etmeyi tercih etmişlerdir. Bu yaklaşım Weick vd.'nin (2005: 409) anlamlandırma (sensemaking) sürecinden türemektedir. Örgüt üyeleri olguları anlamlandırma sürecinde, yukarıda bahsi geçen, bağlılığa dayalı hareket ve davranışlarını meşrulaştıracak şekilde geçmiş bazlı (retrospective) açıklamalar 
geliştirirler (Weick, 2001: 14). Nihayetinde bağlılık, örgüt üyelerinin parças1 bulundukları örgütsel devinimi anlamlı buldukları sürece sürecektir ve tıpk1 davranışlar gibi her anlam bir önceki anlamlandırma sürecinin ürünü olduğundan momentum korunmuş olacaktır. Kökleşmiş anlamların güncellenmesi yadsınamaz bir kesinti (firmanın pazar payını kaybetmesinin ardından küçülmek zorunda kalması ya da büyük bütçeli bir araştırma geliştirme projesinin çıktısı olan ürünün piyasada tutunamaması gibi) olmaksızın mümkün olamayacaktır. Elbette, böyle bir kesinti (veya müdahale) yaşandığında refleksif bir süreç devreye girmez ise sorun aşıldıktan sonra işlevsizliğin nedenlerinin örtük halde var olmaya devam edeceğini vurgulamakta yarar vardır. Böylece, momentum metaforu, bir yandan devinimin kesintisizliğine atıfta bulunurken diğer yandan söz konusu devinimin örgütü işlevsizleştirmesi nedeniyle bir müdahalenin gerekli olduğu mesajını da barındırmaktadır. Müdahaleden kast edilenin yapıcı nitelikli çatışmalar olduğunu ifade etmek gerekir. Yapıcı çatışmadan kastedilen örgüt üyelerinin görüşlerini ifade etmelerini teşvik eden bir yönetsel iklimin tesis edilmesidir.

Yönetim kuramlarının tarihi incelendiğinde örgüt ortamında grup içi çatışma kavramını yaratıcı bir deneyim olarak tanımlayan ilk kuramcının Mary Parker Follett olduğu gözlemlenmektedir. Yönetim işlevinin amacının örgütü 'yek' değil 'bütün' haline getirmek olduğunu vurgulamış, çatışmanın işleyişi bozan ve verimliliği budayan bir durum olmasından ziyade örgüt üyelerinin iş deneyimlerinin entegrasyonunu mümkün kılarak yeni değer (ve anlamların) doğmasını sağladığını öne sürmüştür (Follett, 1924/2013). Böylece çatışma, örgütsel süreçlerde beliren uyarıcı nitelikteki sinyal ve semptomlara dikkat çektiği kadar olağan iş akışında ihmal edilmesi olası yeni bakış açılarının da çözüme dahil olabilmesini sağlamaktadır (Child, 2013: 80). Follett'e göre örgütsel deneyimin yaratıcı bir nitelik taşıması için ise bireylerin aktif katılım göstermeleri gerek-şart olarak görülmelidir (Tonn, 2003: 365).

Her ne kadar yapıcı çatışmanın örgütsel iş süreçlerinde yaratıcı düşüncenin hakim kılınması açısından büyük önemi olduğu öne sürülse de (Johnson, 2015: 28), çatışmanın mutabakat görünümü altında gizli bir hale bürünmesi örgüt açısından istenmeyen sonuçların doğmasına neden olabilir. Harvey (1974) tarafindan geliştirilen Abilene Paradoksu çatışmanın örtük hale gelmesiyle işlevsizlik arasındaki ilişkiyi irdeleyen bir yaklaşımdır. Örgüt üyelerinin, örgütsel iş süreçlerinin akışına dair farkında oldukları işlev bozukluklarını çatışmadan kaçınmak için dile getirmekten sakınıp, yanıltıcı bir uzlaşma görüntüsü vermeleri nedeniyle örgütün arzu edilmeyen sona doğru nasıl ilerlediğini incelemektedir.

\section{ABILENE PARADOKSU}

Jerry B.Harvey tarafından geliştirilmiş Abilene Paradoksu, yayınlandığı 1974 yılından bu yana grup içi karar alma ve buna bağlı örgütsel işlevsizliğin açıklanmasında başvurulan kaynakların arasında yer almaktadır. Bu yaklaşımla örgütsel bağlamda mutabakatın barındırdığı örtük çatışmanın sürdürülemez hale geldiğinde neden olduğu davranışsal kriz ortamının tasviri amaçlanmaktadır (Burke, 2014: 5). Değişim yönetimi alanındaki çalışmalarda da sıkça atıfta 
bulunulan Abilene paradoksu, değişime direncin anatomisinin açıklanmasında yol gösterici bulgular sunmaktadır (McAvoy ve Butler, 2005: 50). Türk Dil Kurumu tarafindan dilimize 'çelişki' olarak çevrilmiş olan paradoks bu yaklaşım bağlamında, örgüt üyelerinin niyetlerinin ve düşüncelerinin tersi yönündeki yönetsel istikamete uyum sağlamaları, hatta destek olmaları durumunu tarif etmek için kullanılmıştır. Abilene adı ise yazarın ailesi ile çıktığı kısa bir yolculuğun ardından ortaya çıkmıştır.

Harvey (1974: 17) bir yaz günü ABD'nin Teksas Eyaleti'ndeki evinde ailesi ile birlikte otururken yaşadıkları yere yaklaşık seksen beş kilometre mesafede Abilene adlı yere yaptıkları yolculuk sonunda aile bireyleri arasında yaşananların örgütsel bağlamda ne kadar sık karşılaşıldığını görmüş ve teşhis ettiği bu örgütsel fenomene yolculuğun yapıldığı kasabanın adını vermiştir. Olayın temelinde, herkes evde vakit geçirmekten memnun olduğu halde içlerinden birinin Abilene'e gitmeyi önermesinin ardından aile bireylerinin, deyim yerindeyse, oyun bozan olmamak için (aslında istemedikleri halde hevesliymiş gibi davranarak) asıl düşüncelerini saklamaları (hatta bunu iyi bir fikir gibi karşılamaları); yolculuk sona erdikten sonra ise seyahatin kötü bir fikir olduğunu söyleyerek bunun için birbirlerini suçlamaları yatmaktadır. Bireyler arasında varmış gibi görünen mutabakat asıl çatışmayı maskeleyerek hem sonucun kötü olmasına hem de çatışmanın derinleşmesine neden olmuştur (Harvey vd., 2004: 216). Harvey (1974: 19) Abilene paradoksunu şöyle tanımlamaktadır: "Örgütler sıklıkla amaçlarının ve niyetlerinin aksi yönde hareket ederek asıl olarak başarmak istedikleri hedefleri yok etme eğilimindedirler." Görünürdeki mutabakat örtük çatışmanın örgüt üyeleri genelinde yaygınlaşmasına ve bireylerin geleceğini bildiği makus sonun kaçınılmaz hale gelerek işlevsiz momentumun korunmasına sebep olmaktadır. Abilene paradoksu ile anlatılmak istenenin netleştirilebilmesi için öncelikle bünyesini oluşturan bileşenlerden bahsetmek, ardından da paradoksun nirengi noktalarını izah etmek yararlı olacaktır.

\section{A. Abilene Paradoksunun Anatomisi}

Abilene paradoksunu altyapısına göz atmak paradoksun bünyesinin anlaşılmasında rehberlik edecektir (Harvey, 1974: 20; Harvey, vd. 2004: 217; McAvoy ve Butler, 2007: 557). McAvoy ve Butler'1n (2007: 560) bir yazılım geliştirme ekibinde çalışanların yeni bir projenin geliştirilmesi sırasında kullanıcı hikayelerinin (deneyimlerinin) iş süreçlerine yansıtılması ile ilgili olarak yaptıkları araştırmanın bulguları (Tablo 1.) paradoksun anatomisinin somut olarak gözlemlenebilmesine olanak sağlamaktadır. 
Tablo 1. Yazılım Geliştirme Ekibinde Çalışanların Bireysel ve Toplu Karar Alma Davranışlarında Gözlemlenen Abilene Paradoksu İlintili Bulgular

\begin{tabular}{|c|c|}
\hline Abilene Paradoksu Semptomu & Araştırma Gözlemleri \\
\hline $\begin{array}{l}\text { Örgüt üyeleri bireysel olarak çözüme yönelik } \\
\text { olarak yapılması gereken doğru yaklaşımı } \\
\text { kabul ederler. } \\
\text { Ancak bu grup içinde dile getirilmez. }\end{array}$ & $\begin{array}{l}\text { Ekipteki her yazılımcı kullanıcı hikayelerinin } \\
\text { (deneyimlerinin) yazılım geliştirme süreci için } \\
\text { önemli bir girdi olduğunu düşünmesine karşın } \\
\text { grup için bunun o kadar da gerekli olmadığını } \\
\text { ifade etmiştir. }\end{array}$ \\
\hline $\begin{array}{l}\text { Örgüt üyeleri karşılaşılan sorunun aşılması } \\
\text { için gerekli çözümün içeriği konusunda } \\
\text { bireysel olarak hemfikirdirler. } \\
\text { Ancak bu grup içinde dile getirilmez. }\end{array}$ & $\begin{array}{l}\text { Ekipteki her yazılımcı, bireysel görüşmelerde, } \\
\text { kullanıcı hikayelerinin geçmişteki yazılım } \\
\text { geliştirme süreçlerine dahil edilebilmiş olsaydı } \\
\text { bugün avantaj yaratacağını ifade etmiş, ancak } \\
\text { grup içinde bundan bahsetmemişlerdir. Denek } \\
\text { kümesindeki iki yazılımcı farklı grup } \\
\text { kombinasyonlarında bireysel yaklaşımlarını } \\
\text { sergileyebilmişlerdir. }\end{array}$ \\
\hline $\begin{array}{l}\text { Örgüt üyeleri kendi görüşlerini gerekçeleri ile } \\
\text { anlatmak yerine fikirlerini kendilerine } \\
\text { saklarlar ve katılmasalar dahi grupta hakim } \\
\text { olan fikre destek verirler. }\end{array}$ & $\begin{array}{l}\text { Kullanıcı hikayelerinin yazılım geliştirme } \\
\text { sürecine kattığ değeri bireysel olarak kabul } \\
\text { etseler de yazılımcılar bunu grup içinde ifşa } \\
\text { etmemişlerdir. }\end{array}$ \\
\hline $\begin{array}{l}\text { Örgüt üyeleri fikirlerini ve çözüm önerilerini } \\
\text { sunmadıkları için görünürde çok katılımlı olan } \\
\text { karar alma süreci sonunda ortaya çıan karar } \\
\text { grup üyelerinin ekseriyetinin görüşlerinin tam } \\
\text { tersi yönde şekillenir. }\end{array}$ & $\begin{array}{l}\text { Kullanıcı hikayelerinin yazılım geliştirme } \\
\text { sürecinde sanıldığı kadar etkili olmadığı yönünde } \\
\text { toplu bir karar alınmasına karşın grup üyelerinin } \\
\text { ekseriyeti bunun doğru olduğuna } \\
\text { inanmamaktadır. }\end{array}$ \\
\hline $\begin{array}{l}\text { Örgüt üyeleri yaşanan sürecin sonunda hayal } \\
\text { kırıklı̆̆ ve hatta öfke hissine kapılarak itham } \\
\text { edilecek birisini bulmaya gayret ederler. }\end{array}$ & $\begin{array}{l}\text { Yazılımcılar arasında bu tür bir eğilimin } \\
\text { olduğuna dair bazı öykülere rastlansa da } \\
\text { araştırma kapsamında somut bir gözlem söz } \\
\text { konusu olmamıştır. }\end{array}$ \\
\hline
\end{tabular}

Kaynak: McAvoy ve Butler (2007: 560)

Abilene paradoksunun oluşmasına yol açan sebepler arasında örgüt içi iletişim kanallarının tıkalı olmasının başta geldiği görülmektedir. Örgüt üyeleri bireysel olarak mevcut örgütsel iş süreçlerinin iyileştirilmesi için neler yapılması gerektiği hakkında çözüm önerileri olmasına veya alınmak üzere olan yönetsel kararın uygulanmasının ardından doğacak işlevsizliği görmelerine karşın örgüt içi iletişim kanallarının sağlıklı işlememesi nedeniyle kişisel bakış açılarını dile getirmekten kaçınarak çoğunluğa uyum sağlamayı tercih ederler. Hatta, daha da vahim şekilde, gidişat asıl düşüncelerinin tamamen aksi istikametine yönelse dahi bu uyumu gösterirler. Harvey vd. (2004: 216)'nin sessizlik spirali olarak adlandırdığı bu durum, karar anında öne çıkan bir ya da birkaç kişinin kendi önerilerini grubun ekseriyetinin fikirlerini temsil eder şekilde sunması karşısında örgüt üyelerinin bireysel olarak kendisini azınlıkta hissetmesi nedeniyle susmalarına atıfta bulunur Banarjee (1992: 799), hiyerarşiden kaynaklanan güç asimetrisi bir kenara, bireyler üzerinde etki sahibi olan grup üyelerinin kendi fikirlerini herkesten önce belirgin hale getirdiklerinde diğer grup üyelerinin sürü 
davranış1 göstererek bu fikri benimsediklerini ifade etmektedir. Elbette, bahsedilmesi gereken bir nokta da çoğunluk-azınlık etkileşimidir. Çoğunluk oluştuğunda örgüt üyelerinin içinden görüşlerini belirtenler çıksa dahi çoğunluktakiler, artık azınlık olanlar tarafından dile getirilenleri dikkate almak hususunda bir bask1 hissetmedikleri gibi rahatlıkla reddedebileceklerdir (Johnson, 2015: 58). Örgütteki iş süreçlerindeki işlevsizliğe dair ortaya konan deliller ne kadar geçerli olursa olsun, momentumu muhafaza eden çoğunluk karşıt görüşlerin doğruluğuna şüpheyle yaklaşıp, yok sayabilecektir (Johnson, 2015 :59).

Sessizlik spiralinin işlevsiz momentumun yapı taşları arasında ilk sırayı alan devinim oryantasyonu ile örtüştügü düşünülebilir. Örgüt üyeleri, mutabakatın aksi yönündeki görüşleri duyulduğunda kendilerinin aleyhine olacağı endişesi ile iş süreçlerindeki maraz akışa göz yumarlar. Yöneticiler açısından görünürdeki mutabakatın yanıltıcı olmasının sessizlik spiralinin de ötesinde bir nedeni vardır. Örgüt üyeleri toplu karar almak için bir araya geldiklerinde birbirlerine hatalı yorumların yapılmasına zemin hazırlayacak şekilde karışık sinyaller gönderirler. Paradoksa adını veren yolculuk önerisi ortaya atıldığında aile üyelerinin her birinin aksini düşünmesine rağmen bu öneriyi 'iyi bir fikir' olarak değerlendirmeleri diğerlerinin kollektif hakikat algılarının bozulmasına neden olmuştur.

Benzer biçimde, McAvoy ve Butler'ın (2007: 560) araştırmasına konu olan yazılım geliştirme ekibinde çalışanların bireysel olarak kullanıcı hikayelerinin iş sürecindeki önemini kavramalarına rağmen bir araya geldiklerinde buna muhalefet etmeleri, diğer yazılımcıların kendi düşünceleri hakkında şüpheye düşmelerine ve kollektif akışa boyun eğerek asıl düşüncelerinin aksi yönünde fikir beyan etmelerine sebep olmuştur (Tablo 1.). Nitekim, Argyris (1994: 82) refleksif olmayan ve içsel motivasyonundan ziyade dişsal motivasyonu araç olarak benimsemiş tek-döngülü öğrenme modelinde bireylerin fikirlerini beyan etmelerinin önündeki engelin, yöneticilerin benimsedikleri iletişim kurma yöntemleri olduğunu ileri sürmekte ve her iki katmanın da, işlevsizliği gidermek istiyor gibi görünse dahi, aslında muhafaza eğiliminde olduğunu vurgulamaktadır. Görünürde çalışanların moralini yükselten ve onlara anlayışla yaklaşarak görüşlerini önemseyen bir tavır sergilenmektedir. Ancak, unutmamak gerekir ki işin görülmesi yönünde harcanacak enerji karşılığında önerilen tatminkar miktardaki ücret ve kariyer imkanları yönetimin yerine getirebileceği vaatlerdir. Bu nedenle, örgüt üyeleri ve yöneticiler arasında örtük biçimde 'ne sen sor ne de ben söyleyeyim' ifadesi ile ortaya konabilecek bir ortam tesis edilmiş olur. Yukarıda bahsi geçen uzmanlığa gereğinden fazla güven faktörü de sahte çatışmasızlık ortamının oluşmasında pay sahibidir. Abilene paradoksu yukarıda bahsi geçen diğer yaklaşımlar ile bir arada değerlendirildiğinde örgütlerde işlevsizlik fenomeninin çerçevesinin şekillenmesinde önemli rol oynamaktadır.

\section{B. Abilene Paradoksunun Nirengi Noktaları}

Abilene paradoksunun tahlilini biraz daha derinleştirerek bu yaklaşımın rasyonel altyapısını incelemekte yarar bulunmaktadır. Harvey (1974: 23) paradoksun beş nirengi noktasından bahsetmiştir. Bunlar sırasıyla devinim 
endişesi, negatif fanteziler, hakiki risk, ayrışma endişesi ile riskin psikolojik eksende ters yönlü hareketi olarak adlandırmıştır. Devinim endişesi, örgüt üyelerinin gördükleri, doğru bildikleri ve inandıkları yönde hareket ederlerse olabileceklere dair hissettiklerini (anxiety) tarif etmektedir. İşlevsizliğin giderilmesi için harekete geçmek yerine verimsizliği kanıtlanmış bir projenin üzerinde çalışılmaya devam ediliyor olmasının altında devinim endişesini bulmak mümkündür.

Hammond vd. (1998: 5) bu durumu batık maliyet tuzağı olarak ifade etmektedirler. Hatadan dönmenin endişe veren bir maliyeti vardır ve bununla yüzleşmek kaçınılan bir durumdur. Örneğin, verdiği kararı yürürlükten kaldıran bir yönetici en başta hatalı bir kararı benimsediğini kabullenmiş olacağı için bundan kaçınmak isteyecek, ancak sırf bu endişe yüzünden maliyetin katlanması pahasına işlevsizliği sürdürerek momentumu muhafaza etmiş olacaktır. Hammond, vd. (1998: 5) bunun en belirgin örneğinin finans kuruluşlarının mali yükümlülüklerini yerine getiremeyen borçlulara sürekli ek kaynak kullandırmaları olduğunu ifade etmektedir. Böylece finans kuruluşu hem borçlu örgütün ileride borçlarını geri öder hale geleceğine dair ümidini korumakta hem de, asıl olarak, en başından kaynak kullandırırken hatalı bir karara imza attığı gerçeğini maskelemektedir.

Harvey'nin (1974: 24) tarif ettiği nirengi noktalarından ikincisi algısal risktir (negatif fantezi). Örgütsel ortamda hakim olan, kurallara ve kültürel kodlara dayalı nedenlerle örgüt üyelerinin bireysel olarak harekete geçme ivmesi yakalayamadıkları bilinmektedir (March, 1989:41). Banarjee (1992: 798) buna ek olarak, bireylerin karar verme ve harekete geçmekte diğerlerinin karar ve düşüncelerinden beklenenin ötesinde etkilendiklerini ve ellerindeki enformasyon ve tahlil aksini gösterse bile grubun kararına meyledeceğini ortaya koyarak bu durumu sürü psikolojisi olarak tanımlamaktadır. Algısal risk, devinim endişesi ile etkileşim içindedir. İşlevsizliğin giderilmesi yönünde harekete geçmeyi gerekli kılan hallerde bunu yapmanın psikolojik maliyetinden sakınmak ve işlevsiz momentumu korumak pahasına dahi olsa grupla birlikte hareket etmek örgüt üyelerine yaşamaları olası içsel çatışmayı yatıştırıcı bir bahane üretme ve sorumluluktan kurtulma imkanı sunar. Bu noktada statükoyu (mevcut durumu) koruma eğiliminin insan davranışı üzerindeki güçlü etkisinden de bahsetmek gerekir. Hammond vd. (1998: 4) statükoyu koruma eğiliminin bireyin egosunu hasardan koruma arzusundan kaynaklandığını belirtmektedir. Bireyin sergilediği davranışın sonuçları kendisini iltifata ya da eleştiriye maruz bırakacaktır. Hangisine maruz kalınacağından emin olunamıyorsa mevcut durumu muhafaza etmek avantajlı gibi yorumlanabilecektir.

Üçüncü nirengi noktası olarak hakiki risk kavramı karşımıza çıkmaktadır. Harvey (1974: 25) örgüt üyelerinin işlevsizliğe tepkisiz kalmalarına neden olan algısal maliyetin gerçekliğini sorgulamaktadır. Diğer bir deyişle, algılanan riskin maliyetinin yüksek olmasından endişe eden örgüt üyeleri iç çatışmalarını grubun içinde kalabilmek için baskılayıp işlevsizliği sürdüren, hatta alevlendiren yönetsel kararlara uyum sağladıklarında, daha büyük ve hakiki olan riski bugünün algısal 
riski ile değiştirerek başarısıllığı ertelemeyi tercih edebilmektedirler. Demek ki, çatışma, özgün karakteristik özellikleri olan bir süreçten ziyade bir semptom olup örgüt üyeleri tarafından hakiki riskten kaçınmak için kullanılmaktadır (Harvey, 1977).

Dördüncü nirengi noktası olarak ileri sürülen ayrışma endişesini Abilene paradoksunun nüvesi olarak değerlendirmek pek de hatalı bir yaklaşım olmayacaktır. Genellikle insanların bilmediklerinden korktuğu söylenegelse de Harvey (1974: 26) insanların asıl korktuklarının, bildiklerinin başlarına gelmesi olduğunu belirtmekte ve örgütsel bağlamda korkuyu dışlanma ve yalnız bırakılma ile sonuçlanan ayrışma korkusu olarak tarif etmektedir. Paradoksun nüvesinde işlevsizliğe karşı gelmenin ardından gruptan dışlanma olasılığının bulunmaktadır. Bedeli gelecekte daha ağır bile olsa momentumun muhafaza edilebilmektedir.

Abilene paradoksunun son nirengi noktası riskin psikolojik eksende ters yönlü hareketidir. Burada Abilene paradoksunun içinde bir başka paradoksun varlığına işaret edilmektedir. İşlevsizliğe son vermek için örgüt üyelerinin kaçındıkları riskin ürkütücü maliyeti olan dışlanma, geleceğe ertelenen daha büyük risk gerçekleştiğinde kaçınılmaz hale gelecektir. Diğer bir deyişle, örgüt üyeleri işlevsiz momentumu korudukları için örgütün deneyimlemek zorunda kaldığı zararın ardından bu zararın maliyeti örgüt üyelerine yansıtılacak (işten çıkarmalar, verilmeyen terfiler, ücret kısıntıları, vb.) ve önü alınamayan bir suçlama dalgası örgüte yayılacaktır. İş süreçlerindeki işlevsizliklerin yol açtığı ağır maliyetler söz konusu olduğunda her birey kendini ortaya çıkan ağır tablonun sorumluluğundan sıyırarak (Tablo 2.) sorumluluğu diğer örgüt üyelerinde aramaya meyledecek ve 'kimin suçu?' sorusunun yanıtını bulmaya gayret edecektir (Taras, 1991: 412; Dekker, 2005: 198).

Tablo 2. Çatışma Türleri

\begin{tabular}{|l|l|}
\hline \multicolumn{1}{|c|}{ Sahi Çatışma } & \multicolumn{1}{c|}{ Sahte Çatışma } \\
\hline Net farklılıkların alenen ifade edildiği çatışma. & $\begin{array}{l}\text { Görünürdeki mutabakatın çöküp örtük } \\
\text { çatışmanın belirgin hale gelmesiyle bireylerin } \\
\text { diğerlerini suçladıkları çatışma. }\end{array}$ \\
$\begin{array}{l}\text { "Bu araştırma projesi teknolojik olarak } \\
\text { uygulanabilir değil." }\end{array}$ & "Projenin işe yaramayacağını söylemiştim." \\
"Verilere baktığımda dediğiniz sonuçlara & $\begin{array}{l}\text { "Beni suçlama. İşini düzgün yapsaydın böyle } \\
\text { olmazdı." }\end{array}$ \\
\hline
\end{tabular}

Kaynak: Burke (2014)’den uyarlanmıştır.

Bilişsel açıdan bakıldığında, insanların başarılardan kendi lehlerine orantısız pay çıkardıklarını ve tam tersi söz konusu olduğunda da kendilerine pek az pay biçtiklerini söyleyebiliriz (Bazerman ve Watkins, 2004: 75). Bunun nedeni insanları, geleceğe dair aşırı iyimserlik içine girmeye iten ve kendilerini diğer insanlarla mukayese ettiklerinde yanılsama yaşayacak derecede pozitif öz değerleme yapmalarını sağlayan pozitif illüzyondur (Martz vd., 1998: 160). Örgütlerde çalışanların niyet ve çıkarımlarını örtük hale getirerek, hayal kırıklığı 
yaşamalarını ve tehditlerle yüzleşmelerini engelleyen savunmacı örgütsel rutinler (Argyris, 1994: 81) pozitif illüzyonun farklı türden bir yansıması olarak yorumlanabilir. Nihayetinde bu savunmacı rutinler hata ve işlevsizliğin farkında olunmasına olanak tanıan geribildirim mekanizmalarının ya tıkanmasına ya da (daha fenası) hatalı yöne sevk edecek biçimde manipüle edilmiş çıktılar üretmesine neden olabilir (Argyris, 1994: 81; Rice ve Cooper, 2010: 8). Üstelik diğerini suçlama eğilimi, cezalandırılma korkusu, hata raporlamasında isteksizlik ve savunmaya geçme gibi, alınan hasarın derinleşmesine neden olacak şekilde örgüt içi sosyal ortamdaki ilişkileri ileri seviyede zedeleyen bir kısır döngüyü tetikleyebilecektir (Rice ve Cooper, 2010: 312). Gözden kaçan şudur ki, işlevsiz momentum, örgütü bir kez Abilene'e götürdü mü bundan herkes sorumludur ve ortaya çıkan maliyet göz önüne alındığında artık herkes kurbandır (Harvey, 1974, 1977; Taras, 1991).

\section{SONUÇ}

İşlevsiz momentum ve Abilene paradoksu ciddiye alınması gereken örgütsel bir patolojinin anatomisi hakkında düşünsel çerçeve çizmektedir. Örgüt içi sosyal davranışın doğası hakkında ayrıntılı iz sürülmesini gerektiren ipuçları veren bu yaklaşımlar, örgütsel bağlamda grup davranışının nasıl maraz bir döngüye dönüşebileceğini göstermeleri açısından bu konuda yapılabilecek araştırmalar için zemin teşkil eden değişkenler sunmaktadırlar.

Bürokratik bir yapıda çalışanların hiyerarşik süreç mimarisinin tasarımından kaynaklanan güç dağılımı nedeniyle işlevsizliğe müdahale edemiyor olması makul karşılanabilir. Bireyler değiştiremedikleri olaylar olduğunda yaşadıkları bilişsel çatışmayı hafifletebilmek için çeşitli yöntemlere başvururlar. Örgütlerde motivasyon kuramları incelendiğinde, örneğin, eşitsizlik kuramı kapsamında bireyin bozulan psikolojik dengesini yeniden tesis etmeye yönelik olarak sarf ettiği emeğin miktarını değiştirmesi, ürettiği çıktının miktarını değiştirmek, algısını değiştirmek, çevresindekilerin görüşlerini etkileyerek onların sarf ettikleri emeğin miktarını değiştirmeye çalışmak, örnek alınan (çıpa işlevi gören) grup ya da bireyleri değiştirmek, performans ile alakalı referans değerlerini değiştirmek ve nihayetinde tüm bunlar işe yaramazsa istifa etmek gibi (Özkalp ve Kırel, 2016: 291-292) rasyonalizasyon ve normalleştirme gayretleri beklenen davranış biçimleridir. Ancak, sonuçları itibari ile örgüte, dolayısıyla da üyelerine büyük zarar verecek sonuçların doğacağını işaret eden, teşhisi mümkün semptom ve sinyallerin göz ardı edilmesi bir yana, Harvey (1974) ve Argyris (1994) tarafından vurgulandığı üzere, nüvesinde dışlanma korkusunu barındıran çok boyutlu bir endişe nedeniyle bunların sürmesine sebep olacak örgütsel karar, prosedür ve politikaların desteklenmesiyle patolojinin örtük hale gelmesi örgüt yönetimi ve örgüt sosyolojisi ve örgüt psikolojisi alanında çalışan araştırmacılar açısından ayrıntılı olarak incelenmeye değer bir konuyla karşı karşıya olunduğunu göstermektedir. 
Bu makalede dikkat çekilmeye gayret edilen incelikli bir konu da çağdaş örgütsel yapılarda çalışanların kendilerini ifade etmelerinin teşvik edildiğini, örgütlerin öğrenen yapılar haline dönüşmeleri gerektiği yönündeki tespitleri, içsel motivasyonun öneminin gündeme getirildiğini sıklıkla duyduğumuz bir zaman diliminde, bu söylemlerin örgütsel süreç rutinlerinde arzu edilen düzeyde karşıllk bulmadığıdır. Özellikle örgütlerde liderlik yaklaşımlarında çağdaş yaklaşımlar göz önüne alındığında örgütsel işlevsizlik ve liderlik arasındaki bağ ile ilgili birçok bulguya erişmek mümkün olabilecektir. Liderliğin örgüt içi sosyal etkileşim ağında gömülü bir hal (Uhl-Bien vd., 2007) olarak yeniden konumlandığ1, liderlik işlevinin örgüt içindeki her üyenin (yönetici olan veya olmayan tüm çalışanlar) üstlendiği bir sorumluluk olduğunun altının çizildiği, bilginin kırılganlığının had safhaya çıktığ (Taleb, 2007) günümüz ortamında örgütsel işlevsizliğin pozitif illüzyon ile kaplanarak yok sayılabileceği düşünülmemelidir.

İşlevsizliğe neden olan psikolojik faktörlerin farkında olmak, bu farkındalığı örgüt geneline yaymak ve meydana gelmemesi için davranışlarının sorumluluklarını alabilecekleri şekilde çalışanların güçlendirildiği (empowerment) yönetsel tercihlere yönelmek hayati önem taşımaktadır. Bireylerin karşılaştıkları işlevsizliklerin giderilmesi sürecinde 'nasıl çözülür?' sorusu kadar (ki makalede ortaya konduğu üzere bu sorunun cevabı bilinmekte ancak dile getirilmemektedir) 'hangi koşullar ve uygulamaların sonucu olarak bu işlevsizlik doğdu?' sorusuna odaklanmaları ve buradan edinilen deneyimin örgütteki diğer iş süreçlerine de nüfuz etmesi için sağlıklı iletişim kurmaları, örgütsel öğrenmenin gerçekleşebilmesi için elzemdir.

Yönetim işlevinin değişen rolünü idrak etmek iyileşmenin ilk adımıdır, zira elverişli örgüt ikliminin oluşması için ortam sağlayıcı konumunda olanlar yöneticilerdir. Yöneticiliği, veri toplayan, seçenekler üreten ve bunları değerlendirerek karar alıp astları tarafından verimli bir şekilde uygulanışını denetleyen bir örgütsel statü olarak gören geleneksel bakış açısı ile işlevsizliğin vereceği zarardan kaçınmak mümkün olmayacaktır. Yöneticilerin, dışlanma endişesinin bireyleri rasyonaliteden uzağa savurabilecek kadar güçlü olduğu gerçeğini içselleştirmesi ve bu endişenin giderilmesinin birinci öncelik olduğunu kabullenmesi gerekmektedir. Duyulmak isteneni söyleyen değil, işlevsizliği teşhis eden, oluşmasında kendi davranışlarının ve kararlarının payını adil olarak tartabilen ve çözüm için gerekli devinimi birlikte çalıştığı örgüt üyeleri ile başlatabilen bireyler işlevsizlik momentumunun inovasyon momentumuna dönüşmesini sağlayacaklardır. Günümüzde, yöneticiden beklenen değişim farkındalığını örgüt tabanına yayması ve değişime katalizör olmasıdır. Akışkanlar çağında var olabilmek için bu anlayışın tesis edilmesinde büyük fayda olduğu görülebilmektedir. 


\section{KAYNAKÇA}

Altunışık, R. (2015), “Büyük Veri: Fırsatlar Kaynağı mı Yoksa Yeni Sorunlar Yumağı mı?”, Yıldız Social Sciences Review, 1(1), 45-76. http://eds.yildiz.edu.tr/YSSR

Argyris, C. (1994), "Good Communication That Blocks Learning.", Harvard Business Review, Temmuz-Ağustos, 77-85. https://hbr.org/1994/07/good-communication-that-blockslearning

Banerjee, A.V. (1992), “A Simple Model of Herd Behavior”. The Quarterly Journal of Economics, 107(3), 797-817. http://www.jstor.org/stable/2118364

Barton, M. ve Sutcliffe, K. (2010), "Learning When to Stop Momentum.". MIT Sloan Management Review, Bahar, 60-76. http://sloanreview.mit.edu/article/learning-when-to-stopmomentum/

Barton, M. ve Sutcliffe, K. (2009), “Overcoming dysfunctional momentum: Organizational safety as a social achievement.". Human Relations, 62(9), 1,327-1,356. doi: $10.1177 / 0018726709334491$

Bauman, Z. (2000/2012), Liquid Modernity. Polity, Cambridge.

Bazerman, M.H. ve Watkins, M.D. (2004), Predictable Surprises: The Disasters You Should Have Seen Coming and How to Prevent Them. Boston, Harvard Business School Press.

Burke, W.W. (2014), "Conflict in Organizations", İçinde: The Handbook of Conflict Resolution: Theory and Practice. Peter T. Coleman, Morton Deutsch ve Eric C.Marcus (Ed.), JosseyBass,

Catino, M. (2013), Organizational Myopia: Problems of Rationality and Foresight in Organizations. Cambridge University Press, Cambridge.

Child, J. (2013), "Mary Parker Follett". İçinde: The Oxford Handbook of Management Theorists. M. Witzel ve M. Warner (Ed.), Oxford University Press, New York, 74-93.

Cialdini, R. (2009), Influence: Science and Practice. Pearson, Boston.

Davenport, T.H. (2014). Big Data at Work. Harvard Business Review Press, Boston.

Dekker, S.W.A: (2005). Ten Questions about Human Error: A New View of Human Factors and Systems Safety. Mahwah, Lawrence Erlbaum Associates.

Dyke, M. (2006). "The role of the 'Other' in knowledge formation, reflection and action in late modernity". International Journal of Lifelong Education, 25(2), 105-123.

Dyke, M. (2009). “An enabling framework for reflexive learning: Experiential learning and reflexivity in contemporary modernity.”. International Journal of Lifelong Education, Vol.28, No.3, s.289-310. http://dx.doi.org/10.1080/02601370902798913

Erol, M. (2001). "Sosyal Entropi'nin Verimlilik Üzerindeki Etkileri”. Cumhuriyet Üniversitesi Íktisadi ve İdari Bilimler Fakültesi Dergisi, 2(1), 127-143.

Fayol, H. (1949). General and Industrial Management. Pitman, London.

Feynman, R. (1995). Fizik Yasaları Üzerine, Çeviri: Nermin Arık, Türkiye Bilimsel ve Teknik Araştırma Kurumu, Ankara.

Finkelstein, S. (2004). Why Smart Executives Fail. Portfolio, New York.

Follett, M.P. (1924/2013). Creative Experience. Martino Publishing, New York.

Hammond, J.S., Keeney, R.L. ve Raiffa, H. (1998). "The Hidden Traps in Decision Making.”. Harvard Business Review, 76(5), 47-58.

Harvey, J. (1974). "The Abilene Paradox: The Management of Agreement". Organizational Dynamics, Vol.3, No.1, s.17-43. doi: 10.1016/0090-2616(74)90005-9

Harvey, J.B. (1977). "Consulting during Crises of Management". İçinde: Current Issues and Strategies in Organization Development, W.W. Burke (Ed.), Human Sciences Press, New York

Harvey, M., Buckley, M.R., Novicevic, M.M. ve Halbesleben, J.R.B. (2004). "The Abilene Paradox After Thirty Years: A Global Perspective”. Organizational Dynamics, 33(2), 215-226. 10.1109/EMR.2008.4490138

Hotten, R. (2015). "Volkswagen: Scandal Explained", http://www.bbc.com/news/business-34324772 (10.06.2016) 
Johnson, D.W. (2015). Constructive Controversy: Theory, Research, Practice. Cambridge, Cambridge University Press.

Koçoğlu, İ., İmamoğlu, S.Z. ve İnce, H. (2011). "The Relationship Between Organizational Learning and Firm Performance: The Meditating Roles of Innovation and TQM.". Journal of Global Strategic Management, (9), 72-88. doi: 10.20460/JGSM.2011515814

Linstead, S., Fulop, L. ve Lilley, S. (2009). Management and Organization: A Critical Text. Palgrave MacMillan, New York.

March, J. (1989). "Rationality, ambiguity and the engineering of choice". İçinde: Decision Making: Descriptive, Normative and Prescriptive Interactions, Editörler: D. Bell, H. Raiffa ve A. Tversty, Cambridge, Cambridge University Press, 33-57.

Martz, J.M., Verette, J., Arriaga, X.B., Slovik, L.F., Cox, C.L. ve Rusbult, C.E. (1998). "Positive illusion in close relationships". Personal Relationships, (5), 159-181. doi: 10.1111/j.14756811.1998.tb00165.x

McAfee, A. ve Brynjolfsson, E. (2012). "Big Data: The Management Revolution”. Harvard Business Review, Ekim Say1s1, 59-68.

McAvoy, J. ve Butler, T. (2005). "Resisting the change to user stories: a trip to Abilene". International Journal of Information Systems and Change Management, 1(1), 48-61. http://dx.doi.org/10.1504/IJISCM.2006.008286

McAvoy, J. ve Butler, T. (2007). "The Impact of the Abilene Paradox on double-loop learning in an agile team". Information and Software Technology, 49, 552-563. http://dx.doi.org/10.1016/j.infsof.2007.02.012

Meyer, J.P, Jackson, T.A. ve Maltin, E.R. (2008). "Commitment in the Workplace: Past, Present and Future". İçinde: The SAGE Handbook of Organizational Behavior Volume-I, J.Barling ve C.Cooper (Ed.), Thousand Oaks, SAGE Publications , 35-53.

Miles, R.E., Snow, C.C., Meyer, A.D. ve Coleman, H.J. (1978). "Organizational Strategy, Structure and Process.". The Academy of Management Review, 3(3), 546-562. doi: 0.2307/257544

Oke, A., Burke, G. ve Myers, A. (2007). "Innovation Types and Performance in Growing UK SMEs. ”. International Journal of Operations \& Production Management, 27(7), 735-753. http://dx.doi.org/10.1108/01443570710756974

Özkalp, E. ve Kırel, Ç. (2016). Örgütsel Davranış, Bursa, Ekin Basın Yayın Dağıtım.

Patnaik, R. (2012). “Strategic Planning Philosophies Continuum.”. IUP Journal of Business Strategy, 9(2), 22-30. https://ssrn.com/abstract $=2164290$

Rice, R.E. ve Cooper, S.D. (2010). Organizations and Unusual Routines: A Systems Analysis of Dysfunctional Feedback Processes. Cambridge, Cambridge University Press.

Salancik, G.R. (1977a). "Commitment and the control of organizational behavior and belief." İçinde: New directions in organizational behaviour. B.M. Staw ve G.R. Salancik (Ed.), Chicago, St Clair Press, 1-54.

Salancik, G.R. (1977b). “Commitment Is Too Easy”. Organizational Dynamics, Yaz Dönemi, 62-80. doi: 10.1016/0090-2616(77)90035-3

Schein, E.H. (2004). Organizational Culture and Leadership, Jossey-Bass, San Francisco.

Taleb, N.N. (2007). The Black Swan: Impact of the highly improbable. Londra, Penguin Books.

Taras, D.G. (1991). "Breaking the Silence: Differentiating Crises of Agreement". Public Administration Quarterly, 14(4), 410-418. http://connection.ebscohost.com/c/articles/7162816/breaking-silence-differentiatingcrises-agreement

Tonn, J.C. (2003). Mary Parker Follett: Creating Democracy, Transforming Management. Yale University Press, New Haven.

Tsoukas, H. ve Cummings, S. (1997). "Marginalization and Recovery: The Emergence of Aristotelian Themes in Organization Studies". Organization Studies, Vol.18, No.4, s.655-683. http://journals.sagepub.com/doi/pdf/10.1177/017084069701800405

Uhl-Bien, M., Marion, R. ve McKelvey, B. (2007). "Complexity Leadership Theory: Shifting leadership from the industrial age to the knowledge era". The Leadership Quarterly, Vol.18, s.298-318. doi 10.1016/j.leaqua.2007.04.002 
Weick, K.E. (2001). Making Sense of the Organization. Blackwell Publishing, Oxford.

Weick, K.E., Sutcliffe, K.M. ve Obstfeld, D. (2005). "Organizing and the process of sensemaking". Organization Science, (16), 409-421. http://dx.doi.org/10.1287/orsc.1050.0133

\section{SUMMARY}

Conflict is inevitable in organizational settings. Depending on the perspective taken about the matter dealing with conflict in organizations requires to embrace a multi-dimensional approach. One of these perspectives suggest that conflict is a catalyst for innovative processes via enabling an eligible environment in which different ideas and views contend with each other eventually leading to emergence of distinct phenomena. Another perspective emphasizes its destructive nature and argues the detrimental effects of conflict among the employees of an organization on organizational efficiency and effectiveness. Both perspectives provide feasible approaches since conflict is a fact that should be managed rather than avoided. On the other hand, there are neglected pernicious influences of conflict on managerial processes when the very phenomenon is concealed in the seemingly achieved consensus.

Abilene Paradox casts light on the embeddedness of conflict among intra organizational communication network and intends to figure out why members of an organization act in contradiction to their original judgment about a decision yet to be made. Dysfunctional momentum preserves its state of motion unless act upon by an external force. Such momentum becomes dysfunctional when people or teams continue to engage in a course of failing action without pausing to recalibrate the ongoing organizational process. Dysfunctional momentum, along with Abilene Paradox, intends to eexplicate the psychological and cognitive roots of the prevailing inertia in organizational settings. This conceptual paper intends to diagnose organizational dysfunctionality from a managerial lens through operationalizing the arguments postulated by these approaches and draw a comprehensive framework with an attempt to create awareness about insidious conflict in organizational processes. 